Grażyna NOWICKA

IEiB UKSW Warszawa

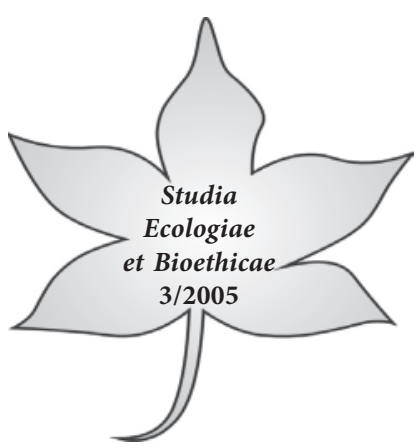

\title{
Ryby - źródło wielonienasyconych kwasów tłuszczowych o kluczowym znaczeniu dla zdrowia: wpływ rtęci na obniżenie ich prozdrowotnego działania
}

Przeszło 30 lat temu zaobserwowano, iż Eskimosi, których dieta opiera się na tłustych rybach morskich, rzadko chorują na choroby układu krążenia takie jak choroba niedokrwienna serca, zawał mięśnia sercowego $(1,2)$. Obserwacje te dały początek licznym badaniom epidemiologicznym, klinicznym i doświadczalnym mającym na celu wyjaśnienie tego zjawiska. Obecnie nie ulega wątpliwości, iż ryby będące źródłem niezbędnych nienasyconych kwasów tłuszczowych z grupy n-3 (n-3 PUFA) są ważnym składnikiem pożywienia, gdyż zawarte w nich kwasy tłuszczowe istotnie wpływają na szereg przemian metabolicznych i tym samym na ryzyko rozwoju różnych chorób $(3,4)$.

\section{N-3 PUFA i ich efekt metaboliczny}

Kwasy tłuszczowe są kwasami organicznymi o alifatycznym łańcuchu węglowym rozpoczynającym się grupą karboksylową $(\mathrm{COOH})$ a zakończonym grupą metylową $\left(\mathrm{CH}_{3}\right)$. Łańcuch węglowy może zawierać tylko wiązania pojedyncze i wówczas mamy do czynienia $\mathrm{z}$ kwasami nasyconymi, bądź zarówno wiązania pojedyncze jak i podwójne i wówczas mamy do czynienia z kwasami nienasyconymi. Nienasycone kwasy tłuszczowe dzielimy zaś na kwasy jednonienasycone (zawierające w łańcuchu jedno wiązanie podwójne) i kwasy wielonienasycone (zawierające kilka wiązań podwójnych). Wśród wielonienasyconych kwasów tłuszczowych szczególne miejsce z fizjologicznego punktu widzenia zajmują kwasy, które posiadają wiązania podwójne przy 3 i 6 węglu licząc od końca łańcucha tzn. od grupy metylowej $\left(\mathrm{CH}_{3}\right)$. Kwasy te nazywamy kwasami z rodziny n-3 (lub $\omega-3$ ) oraz z rodzinyn-6 (lub $\omega-6$ ) Są to tzw. niezbędne nienasycone kwasy tłuszczowe, których organizm człowieka nie umie syntetyzować de novo i musi je dostarczać wraz z pożywieniem. Prekursorem kwasów z rodziny n-3 ( $\omega-3)$ jest kwas alfa-linolenowy, a prekursorem kwasów z rodziny n-6 (®-6) jest kwas linolowy. Są to kwasy, których łańcuchy składają się z 18 atomów 
węgla. Kwas linolowy (n-6 PUFA) jest szeroko rozpowszechniony w przyrodzie, a duże jego ilości występują w produktach roślinnych, zwłaszcza w nasionach roślin oleistych. W organizmach ssaków w dużej ilości występuje jego pochodna - kwas arachidonowy (20-węglowy o 4 wiązaniach podwójnych). Kwas alfa-linolenowy (n-3 PUFA) jest znacznie mniej rozpowszechniony niż linolowy. Duże ilości pochodnych tego kwasu o dłuższych łańcuchach węglowych tzn. kwasu eikozapentaenowego (EPA - 20 węglowy o 5 wiązaniach podwójnych) i kwasu dokozaheksaenowego (DHA - 22 węglowy o 6 wiązaniach podwójnych) występują w rybach. Dlatego ryby są dla człowieka ważnym źródłem kwasów z rodziny n-3 PUFA.

Niezbędne nienasycone kwasy tłuszczowe są ważnym składnikiem fosfolipidów błon komórkowych i substratami do produkcji eikozanoidów (5). Eikozanoidy to grupa związków o szerokim działaniu biologicznym w skład, której wchodzą: prostaglandyny, tromboksany i leukotrieny. Występują one w komórkach różnych tkanek. Tromboksany są syntetyzowane w płytkach krwi. Uwolnione do krążenia powodują agregację płytek oraz skurcz naczyń. Natomiast syntetyzowane w śródbłonku naczyniowym prostacykliny, należące do prostaglandyn, są antagonistami tromboksanów. Inne prostaglandyny wpływają $\mathrm{m}$.in. na procesy skurczu i rozkurczu mięśni gładkich, w istotny sposób regulują pracę różnych narządów np. naczyń krwionośnych, serca, przewodu pokarmowego, oskrzeli. Leukotrieny odgrywają ważną rolę w procesach zapalnych m.in. poprzez wpływ na migrację białych krwinek do ognisk zapalnych, wzrost przepuszczalności naczyń.

Kluczowymi substratami do syntezy eikozanoidów są kwas arachidonowy, należący do rodziny n-6 PUFA, oraz kwas eikozapentaenowy, należący do rodziny n-3 PUFA. Jednak biologiczna aktywność związków powstających z tych kwasów jest różna. Eikozanoidy syntetyzowane z n-6 PUFA silniej stymulują procesy agregacji płytek i skurczu naczyń niż eikozanoidy syntetyzowane z n-3 PUFA. Wzrost spożycia wielonienasyconych kwasów tłuszczowych z rodziny n-3 wiąże się ze zmniejszeniem zdolności płytek do agregacji a więc zmniejszeniem prawdopodobieństwa powstawania zakrzepów, a także obniżeniem odpowiedzi zapalnej organizmu na atak patogenów, obecność toksyn oraz uszkodzenie tkanek (6). Wiadomo, że nadmierna stymulacja procesu zapalnego odgrywa ważną rolę $\mathrm{w}$ rozwoju takich chorób jak np. reumatoidalne zapalenie stawów, astma, alergie, a także miażdżyca i choroby układu krążenia powstające na jej tle.

W śródbłonku naczyniowym kwasy z rodziny n-3 regulują produkcję tlenku azotu, który jest ważnym czynnikiem odpowiadającym za prawidłową relaksację naczyń $(4,7)$. Wpływają także na przepływ jonów sodu i potasu przez błony komórkowe oraz na funkcjonowanie kanałów wapniowych. Wywierają ponadto istotny wpływ na gospodarkę lipidową prowadząc przede wszystkim do obniżenia stężenia triglicerydów oraz obniżenia lipemii popokarmowej, co sprzyja utrzymaniu prawidłowego obrazu lipoprotein (8-10). 
Ryby - źródło wielonienasyconych kwasów tłuszczowych o kluczowym znaczeniu dla zdrowia...

Prawidłowość przebiegu różnych procesów zachodzących w organizmie zależy od utrzymania odpowiednich proporcji między związkami syntetyzowanymi z n-6 PUFA a związkami syntetyzowanymi z n-3 PUFA (11). Znacznie większe rozpowszechnienie w przyrodzie kwasów tłuszczowych z rodziny $\mathrm{n}-6$ niż z rodziny $\mathrm{n}-3$ sprawia, że bardzo często w naszej diecie, a w efekcie w naszym organizmie, dominują kwasy n-6 PUFA i one są kluczowym substratem enzymów odpowiedzialnych za syntezę eikozanoidów.

\section{N-3 PUFA a obniżenie ryzyka rozwoju chorób układu sercowo-naczyniowego}

Liczne już dziś obserwacje epidemiologiczne oraz wyniki badań interwencyjnych u osób z udokumentowaną niedokrwienną chorobą serca, po przebytym zawale mięśnia sercowego wskazują, iż regularne spożywanie ryb wiąże się $\mathrm{z}$ istotnym obniżeniem ryzyka wystąpienia incydentów klinicznych i obniżeniem śmiertelności z powodu chorób układu sercowo-naczyniowego (11-13).

W populacjach tradycyjnie charakteryzujących się wysokim spożyciem ryb takich jak Eskimosi zamieszkujący Grenlandię, rdzenni mieszkańcy Alaski, Japończycy stwierdza się niską częstość chorób układu krążenia (12). 20-letnia obserwacja prowadzona w 7 różnych krajach (tzw. Seven Country Study) wykazała, że wśród osób spożywających średnio 30 gramów ryb morskich dziennie śmiertelność z powodu choroby niedokrwiennej serca (ChNS) była o $50 \%$ niższa niż wśród osób rzadko spożywających ryby (14). Amerykańskie badanie US Physicans Health Study pokazały, iż spożywanie w ciągu tygodnia co najmniej jednego posiłku z ryb morskich zmniejsza o 48\% ryzyko nagłej śmierci sercowej (15).

Badania interwencyjne wskazują, że wprowadzenie do diety pacjentów z udokumentowaną ChNS kwasów n-3 PUFA wywiera korzystny efekt zdrowotny.

Badaniach DART (Diet and Reinfarction Trial), w których wzięło udział ponad dwa tysiące mężczyzn po przebytym zawale serca, pokazały, że spożywanie 2 razy w tygodniu tłustych ryb morskich powoduje $29 \%$ obniżenie ryzyka zgonu (16). We włoskich badaniach GISSI obejmujących ponad 2800 osób spożywających 1 gram n-3 PUFA/dzień względne ryzyko nagłej śmierci sercowej zmniejszyło się o 45\%, zgonu z przyczyn sercowo-naczyniowych o 30\%, a zgonu ogółem o 20\% (17).

Badania Lyon Heart Study obejmujące ponad 600 pacjentów z udokumentowaną ChNS pokazały, iż stosowanie diety zawierającej ryby, olej oliwkowy i rzepakowy, nasiona roślin strączkowych, warzywa i owoce spowodowało spadek częstości zawałów mięśnia sercowego o 70\%, zgonów z powodu ChNS o 76\% i zgonów ogółem o 70\% (18).

Metaanalizy dotychczasowych badań jednoznacznie wskazują, że regularne spożywanie ryb zapewniających odpowiedni dowóz kwasów n-3 PUFA wiąże się z mniejszym ryzykiem rozwoju miażdżycy i chorób układu sercowo-naczyniowego oraz nagłej śmierci sercowej $(19,20)$. 


\section{Inne prozdrowotne działania n-3 PUFA}

Wielonienasycone kwasy tłuszczowe z rodziny n-3 ( $\omega-3)$ odgrywają kluczową rolę w prawidłowym rozwoju mózgu i rogówki u noworodków $(21,22)$. Podczas rozwoju płodowego kwasy te przenoszone są przez łożysko, zaś po urodzeniu muszą być dostarczane z pożywieniem. Dlatego znajdujemy je w mleku kobiecym oraz w produkowanych mieszankach przeznaczonych do żywienia niemowląt. Ponieważ głównym kwasem niezbędnym do prawidłowej budowy komórek mózgowych i rogówki jest kwas dokozaheksaenowy (DHA), a zwłaszcza wcześniaki charakteryzują się niską zdolnością wytwarzania tego kwasu z kwasu alfa-linolenowego, to w mieszankach dla niemowlą stosuje się dodatek zarówno kwasu alfa-linolenowego jak i kwasu dokozaheksaenowego. Znaczenie kwasów z rodziny n-3 dla prawidłowego rozwoju niemowląt wskazuje również na konieczność zapewnienia odpowiedniej ilości tych kwasów w diecie kobiet karmiących. Niedobory kwasów n-3 PUFA mogą prowadzić do zaburzeń widzenia, zaburzeń rozwoju funkcji poznawczych $(23,24)$.

N-3 PUFA wpływają również na prawidłowe działanie układu immunologicznego (25). Efekt ten wiąże się przede wszystkim z wykorzystywaniem tych kwasów do produkcji eikozanoidów i rolą tych związków w regulacji odpowiedzi immunologicznej organizmu, a także bezpośrednim wpływem n-3 PUFA na ekspresję różnych genów (26). Badania pokazały, że n-3 PUFA hamują produkcję prozapalnych cytokin i modulują ekspresję molekuł adhezyjnych. Uważa się, iż mogą one być pomocne w leczeniu zaburzeń związanych $\mathrm{z}$ rozwojem stanu zapalnego, leczeniu pacjentów poddawanych rozległym zabiegom chirurgicznym. Obserwacje kliniczne wskazują ponadto na użyteczność n-3 PUFA w prewencji i leczeniu chorób o podłożu alergicznym takich jak np. atopowe zapalenia skóry $(6,26)$.

\section{Rtęć i jej wpływ na obniżenie prozdrowotnego działania ryb}

Zanieczyszczenie środowiska sprawia, że w ciele ryb może dochodzić do akumulacji substancji niekorzystnie wpływających na zdrowie człowieka takich jak np. związki rtęci, polichlorkowe bifenole, dioksyny.

Ostatnio szczególną uwagę zwrócono na zanieczyszczenie wód morskich związkami rtęci i akumulację zwłaszcza rtęci metylowanej w organizmach ryb morskich będących w diecie człowieka kluczowym źródłem wielonienasyconych kwasów tłuszczowych z rodziny n-3 (27).

Rtęć jest pierwiastkiem naturalnie występującym w środowisku i od dawna znany jest jej niekorzystny wpływ na zdrowie człowieka (28). Rozwój przemysłu i związane z tym m.in. nasilenie procesów spalania węgla i usuwania odpadów komunalnych powodują istotny wzrost poziomu rtęci w atmosferze. Pierwiastek ten ma zdolność szybkiego rozprzestrzeniania się, toteż wzrost jego poziomu ob- 
Ryby - źródło wielonienasyconych kwasów tłuszczowych o kluczowym znaczeniu dla zdrowia...

serwowany jest także w obszarach oddalonych od źródeł jego wytwarzania (29, 30). Utlenione formy rtęci są absorbowane na powierzchni gleby i wody, gdzie ulegają metylacji w reakcjach zależnych od obecności odpowiednich bakterii i przekształceniu w jedną z najbardziej toksycznych form tzw. rtęć metylowaną $\left(\mathrm{CH}_{3}-\mathrm{Hg}\right)$. Metylowana rtęć jest w bardzo wysokim stopniu (ok.95\%) absorbowana przez organizmy biologiczne i w nich akumulowana (31). Wykazano, że pewne gatunki zwierząt, do których należą: wieloryb, szczupak, miecznik, tuńczyk kalifornijski, rekin charakteryzują się wysoką zdolnością do akumulacji rtęci metylowanej. Inne jak łosoś, dorsz czy makrela zawierają znacznie mniejsze ilości tego związku (27).

Długotrwałe narażenie na organiczne i nieorganiczne związki rtęci może prowadzić do uszkodzeń rozwoju płodu, uszkodzeń mózgu, nerek, wątroby oraz serca $(28,32)$. Wyniki dotychczasowych badań sugerują, iż zwiększenie ekspozycji na związki rtęci może zwiększać ryzyko wystąpienia zawału serca $(33,34)$. Akumulacja tych związków w rybach morskich może zmniejszać kardioprotekcyjne działanie wielonienasyconych kwasów tłuszczowych z rodziny n-3.

\section{Zalecenia dotyczące spożycia n-3 PUFA}

W oparciu o dostępne dane dotyczące fizjologicznego działania kwasów n-3 PUFA i ich szczególnej roli w prewencji chorób układu sercowo-naczyniowego, zostały sformułowane i przyjęte przez liczne towarzystwa naukowe (w tym Amerykańskie Towarzystwo ds. Serca) rekomendacje dotyczące spożycia ryb lub izolowanych kwasów n-3 PUFA (35):

1. Dla członków populacji ogólnej zaleca się spożywanie co najmniej 2-razy w tygodniu ryb (zwłaszcza tłustych ryb morskich) będących źródłem kwasów EPA i DHA oraz produktów żywnościowych będących źródłem kwasu alfa-linolenowego.

2. Dzieci i kobiety w ciąży mogą być szczególnie narażone na szkodliwe działanie związków rtęci akumulowanych w rybach, dlatego te grupy powinny unikać spożywania ryb potencjalnie zanieczyszczonych rtęcią.

Dotychczasowe badania wskazują, że u osób w średnim wieku oraz osób starszych korzyści ze spożywania ryb zgodnie z zaleceniami żywieniowymi przewyższają potencjalne ryzyko związane z zanieczyszczeniem ryb rtęcią.

3. Pacjentom $z$ udokumentowaną niedokrwienną chorobą serca zaleca się spożywanie 1 grama kwasów EPA i DHA (łącznie) w postaci ryb lub preparatów zawierających n-3 PUFA (po konsultacji z lekarzem).

4. U pacjentów $\mathrm{z}$ hipertriglicerydemią można stosować suplementację 2-4 gramów kwasów EPA+DHA, ale tylko pod kontrolą lekarską, gdyż zbyt duża dawka tych kwasów może powodować obniżenie czasu krzepnięcia krwi i wzrost ryzyka krwawień. 
Grażyna Nowicka

Tabela. Dobre źródła pokarmowe wielonienasyconych kwasów tluszczowych z rodziny n-3 (n-3 PUFA).

\begin{tabular}{|c|c|}
\hline $\begin{array}{l}\text { Kwas EPA } \\
\text { C } 20: 5, n-3\end{array}$ & Łosoś, sola, dorsz, tuńczyk, ostrygi, kraby, sardynki \\
\hline $\begin{array}{l}\text { Kwas DHA } \\
\text { C } 22: 6, n-3\end{array}$ & $\begin{array}{l}\text { Dorsz, flądra, halibut, makrela, łosoś, morszczuk, pstrąg, } \\
\text { sola, sardynki }\end{array}$ \\
\hline $\begin{array}{l}\text { Kwas alfa-linolenowy } \\
\text { C } 18: 3, n-3\end{array}$ & $\begin{array}{l}\text { Olej rzepakowy, olej sojowy, brokuły, szpinak, soja, jarmuż, } \\
\text { kapusta }\end{array}$ \\
\hline
\end{tabular}

\begin{tabular}{|c|c|}
\hline n-6 PUFA & n-3 PUFA \\
\hline 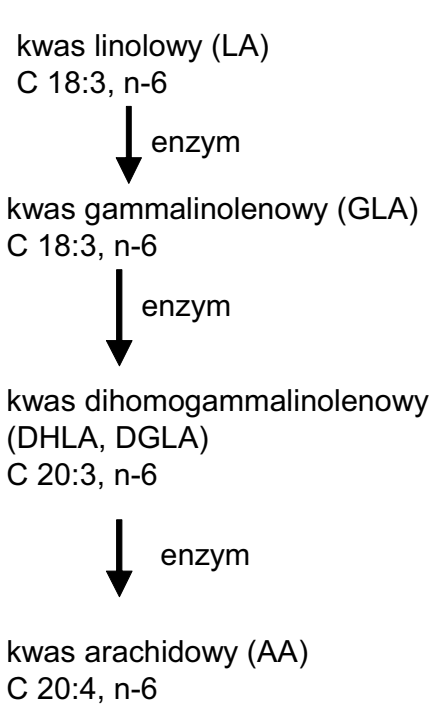 & 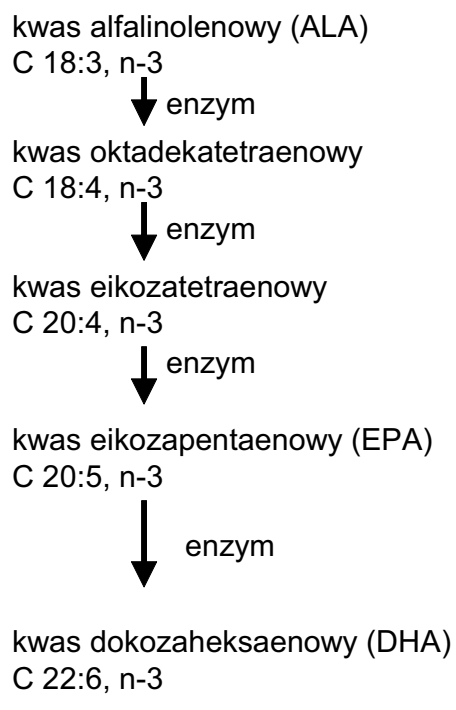 \\
\hline
\end{tabular}

Ryc. Przemiany wieloninasyconych kwasów tłuszczowych z rodziny n-6 (n-6 PUFA) oraz $z$ rodziny $n-3$ (n-3 PUFA).

\section{Piśmiennictwo}

1. Kromann N., Green A. Epidemiologic studies in the Upernavik district, Greenland: incidence of some chronic diseases 1950-1974. Acta Med. Scand. 1980, 208: 401-6.

2. Bang H.O., Dyerberg J., Horne N. The composition of food consumed by Greenland Eskimos. Acta Med. Scand. 1976, 200:69-73.

3. Vanschoonbeck K., de Maat M., Hemskerk J. W. Fish oil consumption and reduction of arterial diseases. J. Nutr. 2003, 133:657-60. 
Ryby - źródło wielonienasyconych kwasów tłuszczowych o kluczowym znaczeniu dla zdrowia...

4. Bigger J. T., Et-Sherif T. Polyunsaturated fatty acids and cardiovascular events. A fish tole. Circulation 2001, 103:623-25.

5. Gertig H., PrzysŁawski J. Tłuszcze pokarmowe a biosynteza eikozanoidów. Żyw. Człow. Metab. 1995, 22:3-7.

6. Calder P. C. Dietary modification of inflammation with lipids. Proc. Nutr. Soc. 2002, 61:345-58.

7. KANG J. X., Leat A. Antiarryhythmic effects of polyunsaturated fatty acids: recent studies. Circulation 1996, 94:1774-80.

8. Harris W. S., Connor W.E., Illingworth D. R. et al. Effect of fish oil on VLDL triglyceride kinetics in men. J. Lipid Res. 1990, 31:1549-58.

9. Nestel P.J., Connor W.E., Reardon M.R. et al. Suppression by diet rich in fish oil of very low density lipoprotein production in men. J. Clin. Invest. 1984, 71:82-89.

10. Harris W.S., Connor W.E., Alam N., Illingworth D.R. The reduction of postprandial triglyceridemia in humans by dietary $\mathrm{n}-3$ fatty acids. J. Lipid Res. 1988, 29:1451-60.

11. Wijendran V., Hayes K.C. Dietary n-6 and n-3 fatty acids balance and cardiovascular health. Ann. Rev. Nutr. 2004, 24:597-615.

12. Danglus M.L., Stamler J., Orencia A.J. et al. Fish consumption and the 30-years risk of fatal myocardial infarction. N. Engl. J. Med. 1997, 336:1046-52.

13. Ascherio A., Rimm E.B., Stampfer M.J. et al. Dietary intake of marine n-3 fatty acids, fish intake and the risk of coronary heart disease among men. N. Engl. J. Med. 1995. 332:997-82.

14. Kromhout D., Bosschieter E.B., De Lezenne Coulander C. The inverse relation between fish consumption and 20-year mortality from coronary heart disease. N. Engl. J. Med. 1995, 312:1205-9.

15. Albert C.M., Hennekens CH., O'Donnell C.J. et al. Fish consumption and the risk of sudden cardiac death. J. Am. Med. Assoc. 1998, 278:23-28.

16. Burr M.L., Fehil A.M., Gilbert J.F. et al. Effects of changes in fat fish and fiber intakes on death and myocardial reinfarction: diet and reinfarction trial (DART). Lancet 1988, 2:757-61.

17. GISSI-Prevenzione Investigators. Dietary supplementation with n-3 polyunsaturated fatty acids and vitamin $\mathrm{E}$ after myocardial infarction: results from GISSI-Prevenzione trial. Lancet 1999, 354:447-55.

18. De Lorgeril M., Salen P., Martin J.L. et al. Mediterranean diet, traditional risk factors and the rate of cardiovascular complications after myocardial infarction: final report of the Lyon Heart Study. Circulation 1999, 99:779-85.

19. Bucher H.C., Hengstler P., Schindler C., Meier G. N-3 polyunsaturated fatty acids in coronary heart disease: A meta-analysis of randomized controlled trials. Am. J. Med. 2002, 112:299-304. 
20. Whelton S.P., He J., Whelton P.K. et al. Meta-analysis of observational studies on fish intake and coronary heart diseases. Am. J. Cardiol. 2004, 93:1119-23 .

21. Connor W.E., Neuringer M., Reisbich S. Essential fatty acids. The importance of n-3 fatty acids in the retina and brain. Nutr. Rev. 1992, 50:21-9.

22. Neuringer M., Connor W.E., Lin D.S. et al. Biochemical and functional effects of prenaral and postnatal omega-3 fatty acids deficiency on retina and brain in rheus monkeys. Proc. Natl. Acad. Sci USA 1986, 82:4021-25.

23. Birch E.E., Birch D.G., Hoffman D.R., Uany R. Dietary essential fatty acid supply and visual aculty development. Invest Ophthalmol Vis,Sci. 1992, 33:3242-53.

24. Lucas A., Movley R., Cole T.J. et al. Breast milk and subsequent intelligence quotient in children born preterm. Lancet 1992, 339:261-64.

25. GRImble R.F. Nutritional modulation of immune function. Proc. Nutr. Soc. 2001, 60:389-97.

26. Price P.T., Nelson C.M., Clarke S.D. Omega-3 polyunsaturated fatty acid regulation of gene expression. Curr. Opin. Lipidol. 2000, 11:3-7.

27. Chan H.M., ENGELAND G.M. Fish consumption, mercury exposure and heart disease. Nutr. Rev. 2004, 62:68-72.

28. Agency for toxic Substances and Diseases Registry (ATSDR). Toxicological profile for mercury:http://www.atsdr.cdc.gov./tox-profiles accessed August 3, 2005.

29. JACKsON T.A. Long-range atmospheric transport of mercury to ecosystems, and the importance of antropogenic emissions - a critical review and evaluation of the published evidence. Environ Rev. 1997, 5:99-120.

30. Westcott K., KalfF J. Environmental factors affecting methylmercury accumulation in zooplankton. Can. J. Fish Aqua Sci. 1996, 53:2221-28.

31. Wolfo M.F., Schwarzbach S., Sulaiman R.A. Effects of mercury wildlifa: a comprehensive review. Environ. Toxicol chem. 1998, 17:146-160.

32. Kjellstrom T. Physical and mental development of children with prenatal exposure to mercury from fish. Stage I. Preliminary tests at age 4. Stockholm. National Swidish Environmental Protection Board, 1986 (Report 3080).

33. Yoshizawa K., Rimm E.B., Morris J.S. et al. Mercury and the risk of coronary heart disease in men. N. Engl. J. Med. 2002, 347:1755-60.

34. Plante M., Babo S. Mercury and the risk of myocardial infarction. N. Engl. J. Med. 2003, 348:2151-52.

35. Kris-Etherton P.M., Harris W.S., Appel L.J., for the AHA Nutrition Committee. Omega-3 fatty acids and cardiovascular disease. New recommendations from the American Heart association. Arterioscler. Thromb. Vasc. Biol. 2003, 23:151-152. 
Ryby - źródło wielonienasyconych kwasów tłuszczowych o kluczowym znaczeniu dla zdrowia...

\title{
Fish derived polyunsaturated fatty acids and their health effects: the influence of mercury
}

\begin{abstract}
Fatty acids derived from fish and fish oils have a strong beneficial effect on cardiovascular health and neurodevelopment. Dietary omega 3 fatty acids prevent cardiovascular disease development by the influence on eicosanoid synthesis, cytokine and growth factors production, lipid and lipoprotein metabolism, endothelial relaxation. They have a strong antiarrhytmic action on the heart. Enhanced consumption of fish derived fatty acids is related to the low incidence of cardiovascular events and sudden cardiac deaths. High content of mercury in some fishes may attenuate the beneficial effects of omega 3 fatty acids on cardiovascular health and also on neurodevelopment of newborns and children.
\end{abstract}

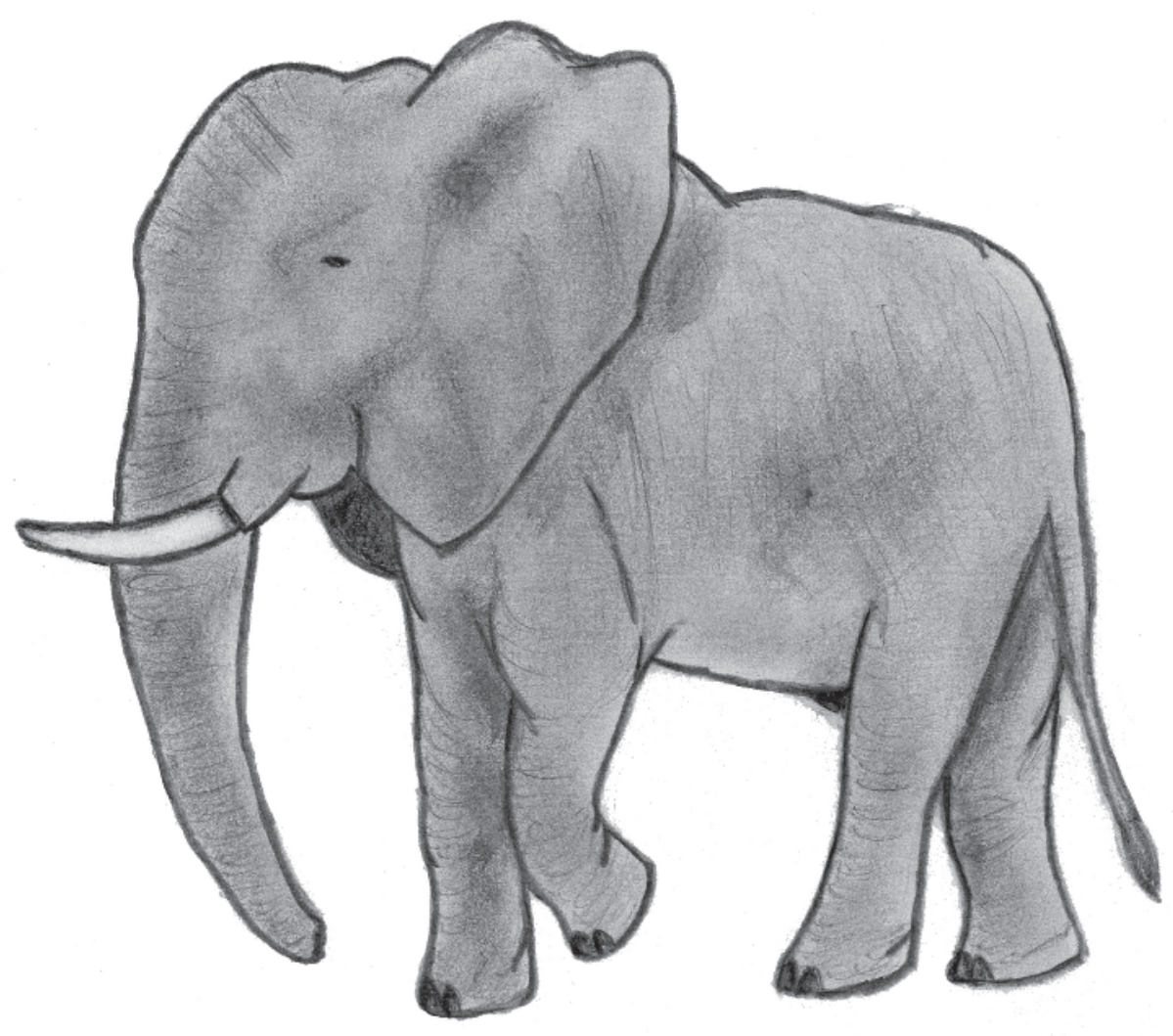

Rys.Aleksandra Tomicka 